\title{
REFLEXÕES SÔBRE DIREITO E PROCESSO
}

CÂNDIDO R. DINAMARCO

SUMÁRIO: 1. nasce o direito processual - 2. Windscheid e Muther - 3. os têrmos da questão - 4. formação gradual do direito $\mathbf{- 5}$. a tese unitária na Itália - 6. Calamandrei e Carnelutti - 7. panprocessualismo - 8. Chiovenda e Liebman 9. polêmica recente - 10. Fazzalari - 11. crítica: direito romano e common law - 12. crítica: filosofia do direito - 13. crítica: direito positivo 14. figuras particulares - 15. aplicações.

1 - Nasce o direito processual. - ciência do direito processual teve o seu assento de nascimento na obra de Von Bülow sôbre as exceções e pressupostos processuais, publicada na Alemanha, em 1.868. Antes disso, as normas do processo eram feitas segundo ditames exclusivamente práticos e estudados pelo critério meramente exegético, à moda dos velhos praxistas, e não havia uma construção segura dos institutos processuais e muito menos uma coordenação harmoniosa entre êles, os quais eram geralmente tratados por romanistas e civilistas - o que bem indica como à consciência dos juristas de então não transparecera ainda a luz da distinção (hoje não nítida) entre o direito substancial e o processo; não havia maturidade suficiente dos estudos, para se compreender que não são de direito material institutos como o da coisa julgada, da hipoteca, da prova, da responsabilidade executiva, da ação. Desta, dizia Savigny que é um direito novo nascido da violação do direito subjetivo, enquanto um slogan francês proclamava que ela é o próprio direito, encouraçado e armado para a guerra. $E$ tudo isso era muito natural naquele mundo tão individualista que o mundo viu no século XIX, o qual impostava as relações entre Estado e indivíduo em têrmos tais que o princípio da autoridade vinha diluído entre exageradas aplicações do princípio da liberdade, e para o qual a igualdade jurídica, mãe de tantas injustiças, era um animal sagrado em que não se devia tocar; naquele mundo ultra-liberal, era natural também que o processo fôsse visto 
como o campo onde os particulares travam o duelo de seus interêsses substanciais, e não como um dos possíveis instrumentos para a realização publicística dos preceitos materiais contidos no ordenamento jurídico; era natural que se acreditasse ser escopo do processo a tutela jurídica de direitos ou de interesses privados; e era natural afirmar-se que a ação é um direito que se exerce contra o adversário, não perante o Estado.

A obra de Von Bülow foi uma revolução. Dava-se então excessivo pêso ao sentido erimológico da palavra processo e à observação (meramente formal) daquilo que o processo tem de mais visível, ou seja, o seu caráter evolutivo, a marcha, o progresso, a evolução, e então era êle entendido como mero procedimento, como caminhada avante, ao longo do arco que vai de um ato de iniciativa a um ato final. Von Bülow abriu os olhos dos estudiosos para o outro lado do instituto, mostrando que há também entre o juiz e as partes uma relação, progressiva sim, mas verdadeira relação jurídica, por fôrça da qual de um lado, o juiz assume a concreta obrigação de decidir e realizar o direito deduzido em júzo, e de outro, as partes ficam obrigadas, perante êle, a prestar uma colaboração indispensável e a submeter-se aos resultados dessa atividade comum; era uma relação jurídica de direito público, diversa da relação substancial litigiosa em seus requisitos constitutivos (pressupostos processuais). Era, enfim, a relação jurídica processual.

Von Bülow não foi, na realidade, o primeiro a ter a intuição da existência dessa relação jurídica processual. Antes dêle, já tinha sido feita uma referência a esta na obra de Bethmann-Hollweg, que êle próprio cita. O seu mérito indiscutível foi o de apresentar sistemàticamente a teoria, a qual fôra anteriormente objeto de um simples aceno. Vieram depois sérias disputas a respeito (a relação é linear, angular ou triangular?), contestou-se a validade da descoberta, mas é uma verdade reconhecida pelos processualistas de hoje que a teoria da relação jurídica processual foi o marco inicial da independência do direito processual civil como ramo autônomo na árvore do direito. Só a partir daí é que foi possível o desenvolvimento científico do direito processual e o encaminhamento da solução de suas questões fundamentais (especialmente daquelas referentes aos seus institutos básicos: jurisdição, ação, processo). (1)

2 - Windscheid e Muther. - Mas também Von Bülow era um homem do seu tempo, e ninguém consegue, de um salto, renegar tôda uma cultura sedimentada e passar para uma dimensão diversa,

(1) Von Bülow, Die Lehre von den Processeinreden und die Processvoraussetzungen, especialmente cap. I. 
um plano estanque, imune a todo e qualquer influxo das doutrinas precedentes. Assim é que, p. ex., em sua obra está dito com tôdas as letras que a relação jurídica processual é constituída através da litiscontestatio, um contrato de direito público do qual nascem o poder e o dever concretos do juiz e a sujeição das partes (afirmação que repugna à ciência processual moderna). Além disso, êle toma decidida posição na velha mas sempre nova dispuía acêrca da unidade do ordenamento jurídico, acusando com isso um reflexo daquela que foi a mais célebre das polêmicas que jamais interessaram o direito processual, e que era então fato bastante recente.

Trata-se da famosíssima polêmica entre os romanistas alemães Berhard Windscheid (então professor na Universidade de Greifswald) e Theodor Muther (Universidade de Konisberg), travada nos anos 1.856 e 1.857 .

Primeiro, Windscheid escreveu um livro sôbre a actio romana, preocupando-se antes de tudo em demonstrar como os sistemas jurídicos romano e.moderno - fossem fundamentalmente diversos, no sentido de que o primeiro, em vez de ser um sistema de actiones, e não se chegava ao direito senão através da actio. E Windscheid propôs-se a traduzir em têrmos modernos a terminologia romana, em primeiro lugar contestando o paralelismo entre a actio e a ação moderna (Klage, Klagerecht), e depois chegando a conclusão de que aquela expressão latina representa um fenômeno que no direito moderno é representado pelo nome de Anspruch (palavra que, no mundo latino, é traduzida por pretensão, ou por razão), o qual é uma situação jurídica substancial, distinta da ação e do direito subjetivo: é a faculdade de impor a própria vontade em via judiciária.

A resposta de Muther foi essencialmente no sentido da reaproximação dos conceitos romano e moderno (actio e ação), sustentando que em Roma também havia prioridade do direito à ação, que esta era o direito à prestação da tutela jurídica (direito à emissão da fórmula), tendo por titular passivo o magistrado, não o adversário.

E bom notar que a obra de Windscheid gozou muito mais do favor do público do que a do seu adversário. Influíram nisso, certamente, vários fatôres extrínsecos, entre os quais se apontam o maior prestígio de que já gozava o professor de Greifswald à época da polêmica (tinha já trinta e nove anos, em seu ativo constavam várias obras, era catedrático há dez anos, ao contrário de Muther, que contava apenas trinta anos de idade, havia anteriormente escrito pouco e só recentemente subira à cátedra), bem como o antipático tom irônico usado por êste último; além disso, Windscheid haveria de 
continuar brilhantemente a sua carreira de romanista, chegando a escrever as famosas Pandetas (Lehrbuch des Pandektenrechts), ao contrário de Muther, que passou a interessar-se de outras diferentes pesquisas jurídicas. E a teoria de Windscheid acabou sendo consagrada em lei (§ 194 do BDB, código civil alemão, na redação de cujo projeto colaborou Windscheid). $\left({ }^{2}\right)$

3 - O têrmos da questão. - A polêmica entre os dois romanistas haveria de exercer enorme influência no sucessivo desenvolvimento dos estudos de direito romano, de direito civil e de teoria geral do direito, abrindo estradas para a fundação do direito processual científico. Ela, de fato, estimulou a teoria do direito subjetivo como poder de exigir uma prestação alheia (que tantos embaraços iria criar à teoria do processo), preparou o campo para todo o vigoroso progresso da teoria da ação (p. ex., é inegável a influência de Muther na teoria de Wach sôbre a ação como direito concreto de agir, ou direito à tutela jurídica), e o que é mais importante, propiciou as especulações metodológicas acêrca das relações entre direito substancial e processo.

$\mathrm{Na}$ verdade, os contendores colocaram o problema da priorida. de da actio ao direito subjetivo com referência ao direito romano (pois, para o direito atual, ambos aceitavam que a ação fôsse um direito novo, nascido da violação de um direito subjetivo precedente), - mas a discussão despertou a doutrina para a existência de dois planos a observar, o substancial e o processual, distinção essa que veio exposta sistemàticamente na obra de Bülow, onze anos após encerrada a polêmica. Só assim é que se tornaria possível a dúvida sôbre as relações que processo e direito (material) mantêm entre si, ou seja, sôbre a conceituação unitária ou dualista do ordenamento jurídico; dúvida essa que, em palavras pobres, tradicionalmente se expressa na pergunta: 0 direito subjetivo nasce mediante o exercício da atividade desenvolvida no processo, ou é anterior a ela? a jurisdição é uma função criativa de direitos, ou meramente recognitiva de direitos preexistentes?

Preferir a primeira solução (o direito nasce do processo) é dizer que as normas jurídicas concretas se produzem ao longo do arco da colaboração entre as chamadas atividades legislativa e judiciária do Estado: 0 direito subjetivo nasce com $\circ$ processo e com a sentença,

(2) - Von Bülow, Die Lehre, cit., cap. I, I; Windscheid, Die Actio des römischen Civilrechts vom Standpunyte des heutigen Rechts, esp. $\S \S 1$ e 23; Muther, Zur Lehre von der römischen Actio, dem heutigen Klegerecht, der Litiscontestation und der Singularsucession in Obligationen, esp. parte 1; Windscheid, Die actio. Abwehr gegen Dr. Th. Muther, esp. §§ 1-23; Pugliese, Introduzione. 
antes dos quais não há senão interêsses relevantes para o direito, interêsses em conflito, mas direito subjetivo não. A norma que rege a concreta relação entre indivíduos depende, para a sua existência, da atividade do juíz.

A segunda solução significa que as atividades legis!ativa e judiciária, mediante as quais desempenha o Estado a sua função jurídica, distinguem-se nìtidamente uma da outra. No plano legislativo, são produzidos preceitos gerais e abstratos, que se tornam concretos e específicos (i. é, que se aplicam) automàticamente, diante do ocorrer de um fato jurìdicamente relevante; e a função jurisdicional não consiste senão em declarar (i. é, reconhecer) essa vontade concreta do ordenamento jurídico e atuá-la pràticamente.

O sabor acadêmico da questão e as dificuldades criadas pelas sutilezas filosóficas e verbais utilizadas na sua discussão não devem desencorajar o estudioso ou desinteressá-lo do problema, pois na realidade são inúmeras as implicações teóricas e práticas da tomada de posição em favor da unidade ou do dualismo do ordenamento jurídico: pode-se mesmo dizer que em todos os problemas institucionais do direito processual se vê um reflexo dessa fundamental questão metodológica (pense-se no conceito da ação, na disputa entre a teoria material e a teoria processual da coisa julgada, na questão se esta impede outro julgamento sôbre a matéria decidida ou impõe que o novo julgamento seja conforme ao primeiro, na determinação do escopo da jurisdição ou do processo, no conceito da sanção executiva, etc.). É, por isso, conveniente esclarecer os diversos aspectos da ques. tão e resolvê-la explìcitamente, para que as soluções parciais possam ser conscientemente coordenadas entre si, em tôrno de um núcleo comum. Os parágrafos seguintes fazem um esbôço (necessàriamente resumido) das diversas variações das duas teorias e da sua sucessão histórica, bem como uma tentativa de apreciação crítica da tese unitária.

4 - Formação gradual do direito. - Foi Von Bülow o primeiro a sustentar, para o direito moderno, a tese da unidade do ordenamento jurídico. Primeiro, foi um simples aceno a ela em sua obra famosa de 1.868 , nos limites de uma nota de rodapé; ali, citando alguns autores alemães precedentes, afirmou que a lei vai do comando abstrato (lex generalis) ao comando concreto (lex specialis contida na sentença) e finalmente à realização dêste (execução), tudo isso significando que o direito (não só o subjetivo, como também o objetivo) sofre uma fundamental transformação através do processo. Em obra posterior a essa, êle apresentou de forma sistemática a tese, dizendo que a função do juíz não é aquela de reconhecer um direito preexistente, nem 
à do processo é a de tutelar um direito privado; as regras contidas na lei limitam-se a fornecer uma trilha obrigatória, mais ou menos precisa, para à formação da norma concreta, mas é o juíz, através do processo, quem vai completar o direito substancial, produzindo a norma concreta. O direito, pois, na concepção de Von Bülow, se forma escalonadamente, a principiar da norma incompleta contida na lei e consumando-se com a sentença que completa essa norma e faz nascer o direito subjetivo do caso concreto.

Outro marco fundamental na história da tese unitária do ordenamento jurídico foi Ke!sen, com a sua doutrina pura do direito. Desenvolveu notàvelmente o jurisfilósofo checoslovaco a idéia da formação gradual do direito, afirmando que êste se produz através de sucessivas etapas - (a. a norma fundamental, imanente na consciência do povo; b. a constituição; c. a lei; d. o decreto; e. o negócio jurídico; f. a sentença; g. a execução), das quais cada qual constitui pressuposto da seguinte e execução da precedente. $O$ direito não impõe um dever-ser ao indivíduo, mas enuncia sanções e lhe mostra qual a conduta com a qual êle poderá evitar a aplicação destas; o cânone que impõe essa conduta é, porém, de natureza social e não jurídica. E a sentença, aplicando a sanção, é também fonte de direito, de natureza totalmente constitutiva e não meramente declaratória do direito preexistente. $\left({ }^{4}\right)$

5 - A tese unitária na Itália. - Essa idéia teve bastante divulgação e prestígio, seja entre os autores alemães (especialmente Binder, que da tese unitária tirou sérias consequências para o direito processual) ou italianos; entre êstes, é fundamental o pensamento de Capograssi, cuias reflexões sôbre a experiência jurídica exercem marcada influência sôbre aquêles que ainda hoje aceitam a unidade do ordenamento jurídico.

$\mathrm{Na}$ verdade, o primeiro a sustentar na Itália essa idéia foi anterior a Capograssi; trata-se de Mortara, segundo o qual o direito subjetivo é que nasce no processo, pois a norma e a pretensão, ainda estando bem próximas, não mantém contato: a sentença opera como - interruptor de eletricidade, que dá passagem à faísca que as unirá, ocasionando o nascimento do direito subjetivo.

Os que vieram depois, e foram tantos, não escondem a influência do filósofo italiano do direito, e não só dêste, mas também de Kelsen. Com variações que não a desnaturam a tese unitária é defendida expressamente, na Itália, de maneira mais destacada, por Peke-

(4) V. Von Bülow, Die Lehre, cap. I, nota 3; Rocco, La sentenza civile, esp. n. 0 50, nota 1; Kelsen, Reine Rechislehre. 
lis, Allorio, Salta Ascarelli, outros dois história do penta história do pensamento processualístico italianol $e$ que são Calamen-a drei e Carnelutti, embora não tratassem monog ficamente do problema, também tem à base dos seus respectivos sisemas a idécia te Kelsen e Capograssi.

Pekelis é particularmente conhecido por um artigo escrito para uma obra enciclopédica, sôbre a ação do direito moderno, no qual nega a existência de direitos subjetivos materiais e de relações subjetivas entre pessoas; o único direito que existe é a ação, que estabelece um vínculo entre o autor e o juiz e outro entre êste e o rév; e, por uma ilusão de ótica, as pessoas crêem que estão relacionadas d retamente entre si, tomando por realidade a sombra (linear) do ângu lo formado por aquelas duas relações.

Para Allorio, as normas jurídicas, mesmo as substanciais, têm como destinatário o juíz. As normas substanciais se conceituam como normas de valoração jurídica, e são estáticas; êle dá particular importância ao momento jurisdicional na gênese da norma concreta, dizendo que esta aparece através do exercício de um poder outorgado por normas de produção jurídica, entre as quais estão as leis do processo. É nítido o sabor Kelseniano de sua teoria, que não dá por produzida a norma substancial concreta senão através do acertamento jurisdicional.

Satta, declarado adepto de Kelsen e Capograssi repudia a teoria estática da jurisdição, nega a existência de direitos subjetivos e afirma que o ordenamento jurídico é realizado pelo próprio ordenamento jurídico, através das atividades conjugadas do juiz e das partes no processo: assim, é neste que se produz a norma concreta. Nas considerações de Satta, o qual na presente fase de sua vida cultural não esconde uma viva vocação para os temas espirituais e filosóficos, o ponto de partida é dado moral homem - é sempre o homem, o qual mantém a sua originária soberania perante o Estado, e de cuja atividade, através do exercício da ação, depende a produção jurídica. O professor da Universidade de Roma, descrente das revistas de direito processual existentes na Itália, em 1969 fundou uma sua, na qual, pràticamente sòzinho, vem depositando o fruto de suas meditações filosóficas e jurídicas. E nessa publicação se vêem renovadas as suas idéias Kelsenianas (embora em alguns pontos Satta pareça criticar Kelsen, com palavras que, todavia, não vão além de mera crítica verbal), seja quando êle defende a teoria normativista contra as críticas de de autôres, escolas e escolinhas que introduzem indevidamente no estudo do direito, indesejáveis dados históricos e sociológicos - seja afirmando que $\circ$ direito é aquilo que o juiz afirma que é direito, que a 
verdadeira relação (lógica e histórica) entre a jurisdição e a legislação é a que evidencia o primado daquela, que a visão unitária do direito é a única que deve ser seguida.

Ascarelli, num artigo escrito em 1957, observou que não a norma constitui objeto da interpretação, mas o texto (o qual, uma vez interpretado, revela a norma). O trabalho do intérprete é, assim, como que uma conexão entre o passado e o futuro, pois com a aplicação concreta êle proieta em direção dêste a formulação abstrata, que é um dado pretérito. Mas, continua o ex-professor da Universidade de São Paulo, em sua indagação histórica o intérprete é obrigado a fazer várias escolhas, seja determinando a ratio do texto analisado ou identificando a hipótese legal abstrata em que o fato acertado se enquadra. E a formulação (concreta) da norma nasce justamente do concurso dessas escolhas, através das quais o intérprete se insere na produção do direito e através das quais os princípios se "positivam", tornando-se imperativos. $\left({ }^{5}\right)$

6 - Calamandrei e Carnelutti. - Êsses dois processualistas nunca dedicaram monografias ao estudo da teoria unitária ou dualista do ordenamento jurídico, mas ambos tem como premissa lógica necessária às suas doutrinas a idéia da inaptidão da lei para reger as relações entre pessoas, da necessidade de uma outra atividade complementar de produção jurídica, do direito que nasce da sentença, e tantas outras coisas que só nas teorias de Kelsen e seus seguidores podemos encontrar.

Todos conhecem o pensamento de Carnelutti sôbre o escôpo do processo. Quando êle diz que êste existe para a justa composição da lide, pressupõe naturalmente que as normas jurídicas substanciais contidas na lei não tenham por si sós aptidão para compô-la (i é, para, qual regra concreta, regular o conflito de interesses). Essa idéia, que está à base de todo o sistema de Carnelutti, foi por êle manifestada num dos seus mais antigos escritos, um trabalho sôbre a sentença condicional. O efeito da sentença, diz êle, é tornar concreto ou particular o preceito abstrato ou genérico contido na norma legal; o comando abstrato é representado por um arco, o qual só se fecha em círculo quando houver o comando complementar; êste reside na sentença (não dispositiva) e no negócio jurídico. E, como se vê, uma derivação da teoria de Kelsen.

(5) Mortara, Commentario, vol. I, n.0 18; Capograssi, Inforno al processo, p. 254, e Giudizio processo scienza verità, p. 7; Pekelis, Azione; Allorio, La Pluralità degli ordinamenti, p. 247; Satta, Diritto processuale civile, n. 2 e 96, e Norma, diritto, giurisdizione; Ascarelli, Giurisprudenza costituzionale e In tema di interpretazione. 
Calamandrei, escrevendo sôbre as atividades do juíz em comparação com a de um historiador, dizia coisas parecidas. Para o processualista toscano, o momento essencial da jurisdição é aquêle em que $\circ$ juiz transforma a norma abstrata (a qual se dirige a todos e a nenhum) em comando concreto; a norma da lei é em si mesma uma hipótese abstrata e inerte, que não pode tornar-se preceito concreto a poder de magia e por isso é necessário que o juíz, inserindo-se na realidade, desempenhe o seu papel de comandar e impor sanções. $\left(^{6}\right)$

7 - Pan-processualismo. - Em um artigo muito recente (1968), Micheli retoma o fio de um seu trabalho anterior e, partindo de uma crítica a Satta e a Ascarelli, sustenta à sua maneira a teoria unitária. Aparentemente, êle faz uma crítica a essa tendência, mas é uma crítica meramente verbal e no fundo a sua tese é uma variação da mesma.

Micheli concorda que a concretização do comando gerâ: abstrato do legislador é obra do intérprete, mas observa que intérprete não é só o juíz, senão também o povo através das normas consuerudinárias, e os próprios interessados, enquanto desenvolvem sua atividade dentro e fora do processo (transação, juizo arbitral, conciliação). Êle leva em conta as reflexões de Fazzalari num trabalho sôbre a experiência do processo e afirma que a experiência jurídica não se circunscreve a êste e ao juízo de um órgão do Estado, mas deve estender-se à consideração de tôda a atividade jurídica realizada pelos sujeitos fora do processo. É pan-processualista, e muito estreita, a visão de quem, como Capograssi e Satta, concentra as suas atenções na utilidade só do processo à concretização do direito. A realidade mostra como o ordenamento jurídico é mais complexo do que dizem as teorias unitárias.

Mas, nem porque busque uma visão mais ampla do fenômeno jurídico, a opinião de Micheli deixaria de ser unitária (essa ampliação, aliás, não é totalmente estranha à obra dos escritores precedentes). Na verdade, êle entende que só há concretização da norma quando há controvérsia; sem esta, haverá mera ałuação expontânea do direito. Mas essa afirmação de Micheli é em si uma veemente negação da teoria dualista, segundo a qual a norma se concretiza automàticamente, independentemente de controvérsia, independentemente de controvérsia, independentemente da consciência ou vonta-

(6) Carnelutti, Diritto e processo, esp. n. 9 e 13, Istituzioni, esp. n. 0 17, e La sentenza condizionale; Calamandrei, Istiłuzioni, esp. $\S \S 8,11$ e 13, e II giudice e lo storico, esp. n.० 8-9. 
de de quem quer que seja, e antes da existência do processo: e a êsse resultado positivamente não chega Micheli. ( $\left.{ }^{7}\right)$

8 - Chiovenda e Liebman. - Posição autênticamente dualista é, em verdade, a de Chiovenda. Também êle não escreveu monogràficamente sôbre a matéria, porém não se limitou a deixar implícito o dualismo à base de sua tese da atuação da vontade concreta da Lei como escôpo do processo: êle em várias oportunidades se manifestou sôbre o assunto, tomando posição bem definida.

No silêncio do principal processualista italiano, já não seria lícito duvidar se êle colocasse ou não a legislação e a jurisdição em planos distintos, ou se considerasse ou não já formada a norma do caso concreto no momento em que o juíz é chamado a intervir. Mas êle disse tantas vêzes, expressamente, que a norma concreta se forma automàticamente com o suceder de fatos previstos na norma abstrata, que ao processo de cognição (condenatório, constitutivo ou meramente declaratório) não toca senão declará-la, e que a função do processo executório é atuá-la pràticamente. Além disso, enfrentou os que sustentam a unidade do ordenamento jurídico, e o fêz tachando de absurda uma das consequências inevitáveis dessa tese (que, no caso de cumprimento voluntário, o elemento produtivo da norma con. creta é a vontade do indivíduo) e mostrando que ela conduziria à conclusão de que os juros moratórios correm a partir do trânsito em julgado da sentença e não a partir da citação.

Também na obra de Liebman sempre foi muito clara a idéia dualística, pois êle, além de adotar plenamente a doutrina de Chiovenda quanto ao escôpo do processo (doutrina que se assenta necessàriamente naquela idéia), em vários de seus trabalhos sustenta que a atividade do juiz no processo é teorética e não volitiva, que a jurisdição não tem eficácia produtiva do direito nem no caso da sentença injusta (mas a tem na hipótese da sentença constitutiva). ${ }^{8}$ )

9 - Polêmica recente. - Também Liebman, porém, situava-se entre aquêles que nunca se preocupam em dedicar trabalhos especiais a essa disputa: sempre lhe bastou ter idéias claras a respeito e pautar a sua produção exclusivamente processualística, segundo essas idéias (que, como vimos, êle expôs aqui e ali). Mas, ainda bem recentemente (1969), um artigo de De Fina provocou uma resposta polêmica do fundador da Escola Processual de São Paulo.

(7) Micheli, L'unità dell'ordinamento; Fazzalari, L'esperienza del processo.

(8) Chiovenda, Principi, esp. § 2.0, 1.11; Liebman, Efficacia ed autoriłà, esp. n. 0 e 10, e Manuale, esp. n. $\circ$ e 26. 
Em seu trabalho, De Fina defende a obra revolucionária com que Satta está procurando comprometer em seus fundamentos a veIha e tradicional estrutura do direito processual e da própria teoria geral do direito; secundando e apoiando incondicionalmente Satta, aquêle livre docente de direito constitucional da Universidade de $\mathrm{Pa}$ lermo sustentou que o direito não reside no ordenamento jurídico, êle é constituído no processo; que êste é o palco onde se identificam ordenamento e jurisdição, ação e postulação do juízo; que em certo momento a norma entra em crise, consumando-se a sua virtude imperativa; que o processo termina onde acaba a eficária da norma.

A resposta do professor da Universidade de Milão foi que, em primeiro lugar, deveriam os desafiantes da velha estrutura demonstrar o êrro básico em que se assentam as impostações tradicionais i. é, demonstrar que a norma não existe, nem o ordenamento, senão dentro do processo. Mas, prossegue, a dimensão social do direito reside iustamente na fôrça vinculante de suas normas, e seria decepcionante se todo o trabalho legislativo não valesse mais do que escrever na água, o que aconteceria se a norma só valesse enquanto obedecida, cessando a sua eficácia quando e se o particular não se agradasse dela. Em suma, disse Liebman que Satta se bate contra uma realidade evidente, contra uma organização feita em moldes que os seus expedientes e sutilezas não conseguem esconder. E acrescentou que é estéril de conseqüências para o direito processual tôda essa filosófica problemática das relações entre a norma e o homem, entre o ordenamento e a coletividade - mas o que é certo e insofismável é a existência da norma e do ordenamento como dados insuprimíveis da realidade objetiva. $\left({ }^{9}\right)$

10 - Fazzalari. - Em favor da tese dualista, escreveu Fazzalari em 1957 um livro em que aborda com muita propriedade essa questão central da teoria geral do processo e deduz as implicações de uma ou de outra das teorias em debate.

O livro começa pondo em relevo os reflexos da polêmica entre Windscheid e Muther sôbre os estudos romanísticos e sôbre a teoria geral do direito; depois de analisar as teorias de Bülow e Kelsen e as suas repercussões na obra de Allorio, Satta, Pekelis e outros, Fazzalari nega que se possa resolver a questão das relações entre direito substancial e processo sub specie aeternitatis, pois não vê por que todo e qualquer ordenamento jurídico deva conter normas primárias e normas sancionatórias, normas substanciais e normas jurisdicionais, preceitos e sanções.

(9) De Fina, Ordinamento e giurisdizione; Liebman, Diritto e giurisdizione. 
$\mathrm{Na}$ análise do direito romano, porém, chega à conclusão de que mesmo aí não havia atividade criativa do pretor, o qual não se inseria no processus da produção do direito nem mesmo na faixa reservada ao jus honorarium. Descendo ao nível do direito positivo italiano, o autor também ali afirma a tese dualista, dizendo que aquêle ordenamento contém três espécies de normas: reguladoras da atividade privada, da atividade dos órgãos públicos (legislativos e executivos) e da atividade jurisdicional.

Depois, tendo feito uma inçursão pela teoria geral do direito (com esclarecimento sôbre o direito subjetivo), passa a estudar as aplicações da teoria dualista em vários institutos processuais, falando sôbre o processo de conhecimento, a causa petendi, a legitimação, o objeto do processo, a ação, o processo de execução, o título executivo, os embargos do executado. $\left({ }^{10}\right)$

11 - Crítica: direito romano e common law. - Foi com referência ao direito romano que começou a ser sustentada com seriedade a tese da unidade do ordenamento jurídico (v. supra, n. ${ }^{\circ}$ ): tendo Windscheid sustentado que o sistema jurídico de Roma era um sistema de actiones, não de direitos, e que a êstes não se chegava senão através daquelas, e tendo dito Muther em resposta polêmica que não, que em Roma a função do proetor era meramente recognitiva, ou interpretativa, estava lançado o germe para as discussões que até hoje atormentam a teoria geral do direito e a do processo. Por isso, é natural que no exame crítico dessa disputa se principie pelo direito romano.

$\mathrm{Na}$ fase nebulosa de sua própria formação, o Estado vai aceitando uma forma de compromisso com as fôrças preexistentes, contentando-se em absorver normas consuetudinárias no ordenamento jurídico positivo, ou mesmo em atuar normas consuetudinárias como tais, ou ainda em emitir decisões fundadas em sentimentos populares não formulados, latentes na consciência comum - e só gradativamente vai insinuando a sua vontade através de normas positivas próprias. E por isso é que constitui ensinamento comumente repetido a prioridade histórica da jurisdição sôbre a legislação, entendido que só quando atinge um certo grau de maturidade o Estado chega a emitir normas com valor erga omnes e caráter abstrato; antes, não o faz por não se sentir suficientemente forte perante os indivíduos para impor os preceitos enunciados.

Ora, quando se fala em direiło romano, entende-se o direito de uma época histórica em que pelas razões vistas o direito substancial

(10) Fazzalari, Note in tema di diritto e processo. 
não emanava todo êle de fontes que se assentassem no poder estatal. Ao lado do jus civile, grande era o número de normas consuetu. dinárias a regerem as relações entre pessoas o Estado romano não era suficientemente forte para impor o seu direito aos estrangeiros (peregrini). Além disso, muitas normas de direito substancial constavam aos editos, espécie de programa normativo mediante o qual cada pretor, assessorado pelo seu consilium de jurisconsultos, ao assumir o cargo prometia distribuir justiça segundo os critérios que enunciava. No entanto, mesmo com referência a um Estado débil assim perante os indivíduos, que não conseguira impor plenamente ainda a fôrça de seus preceitos substanciais genéricos e abstratos, é indiscutível que o direito do caso concreto só nascesse após a pronúncia do magistrado.

Quando a norma aplicada era de jus civile ou de direito peregrino, nem a novação operada pela litiscontestatio parece ser um argumento decisivo em favor da criatividade do direito pelo pretor, pois - julgamento final era sempre de acôrdo com a norma preexistente. E ainda quando a norma era de direito honorário, é mais provável que ainda aí a decisão segundo ela não constituísse uma criação de direito do caso concreto. É verdade que o direito pretoriano é definido como o conjunto de normas que os pretores introduziram para ajudar, suprir ou corrigir o direito civil, em nome da utilidade pública $(D \quad 1,1,7,1$ Papin), sendo que o uso do verbo introduzir dá claramente a idéia de criação do direito, mas, por outro lado, há a afirmação de que proetor jus facere non potest (Gai, 3,32). Assim, se lembrarmos que a divisão de poderes era coisa muito longe de ser conscientemente conhecida na civilização romana, a publicação do edictum perpetuum terá sabor de ato legislativo do pretor, e não de ato jurisdicional; e seremos levados a crer que, quando o mesmo pretor vem a julgar segundo os preceitos estabelecidos no edito (agora, então, desempenhando atividade jurisdicional), a norma levada em conta é anterior à sentença, ainda que criada pela mesma pessoa física que participe do judicium. Além disso, mesmo quando fazia a sua promessa programática anual o pretor não estabelecia arbitràriamente as regras a observar, tirando asas do nada ou de sua vontade; os jurisconsultos que o assessoravam eram afinal (como geralmente se repete) a viva voz do direito, representavam autênticamente o espírito jurídico do povo romano, e seus pareceres muito raramente eram repudiados pelo pretor.

Só pesadas tôdas essas observações, resta muito pequena margem à criatividade pretoriana, e verossimilhança menor ainda à tese da unidade do ordenamento jurídico romano. 
É interessante, ainda, a observação de que assim como no Estado embrionário, também em alguns Estados muitíssimo evoluídos se vêem sistemas em que não há um direito escrito acima do juiz, a Ihe limitar o critério material dos julgamentos: é o que se dá nos países que adotam a common law, sistema jurídico cujo espírito reside na idéia de que os litígios devem ser resolvidos com a ajuda dos princípios obtidos, por indução, da experiência jurídica do passado e não por dedução, das regras estabelecidas arbitràriamente por uma vontade soberana; a razão, e não a vontade soberana, deve ser a justificação profunda da decisão. Trata-se de um sistema eminentemente consuetudinário, cujas normas se revelam através dos órgãos judiciais, em decisões com muito mais possibilidade de aderência às exigências do caso concreto que aquelas fundadas em norma escrita, a qual por sua própria natureza é muito mais rígida que o costume. Nêsse sistema, certos julgados enunciam normas de eficácia vinculativa para o futuro (holding se chama a parte da sentença que as contém), e às quais fica daí em diante adstrito o tribunal.

Porém, ainda nos ordenamentos jurídicos pertencentes à família da common law não é lícito dizer que o juíz cria, na sentença, a norma do caso concreto; ao contrário, é da essência do sistema a decisão segundo os princípios do holding de alguma decisão anterior. Assim, as decisões judiciárias não constituem fonte do direito no sentido de que produzem a norma do caso concreto em julgamento: elas podem ser consideradas fontes, sim, mas apenas pondo-se atenção à fôrça vinculativa que adquirem, como precedente judiciário, com referência a casos futuros (fonte normal). Diante disso, pois, não se pode afirmar, ao menos assim à primeira vista, que a common law seja um sistema de produção judiciária do direito, no sentido que essa expressão é usada nas presentes reflexões.

Nos países de direito escrito, com mais fortes razões, é de criticar a afirmação de que a jurisprudência constitua em si mesma fonte do direito: a autoridade que tem, para efeitos futuros, é de mero fato (rationis imperio, e não ratione imperii), e não há uma fôrça vinculativa dos julgados anteriores, nem dos de grau superior sôbre os futuros juízos dos órgãos subordinados. A Súmula do Supremo Tribunal pode ser $\circ$ início de uma evolução que não se sabe ainda a que pôrto conduzirá, mas o certo é que hoje ela constitui mera auto-limitação (e limitação relativa) que a nossa suprema côrte se impõe, sem qualquer vinculação (no plano jurídico) dos outros tribunais. (11)

(11) Pugliese, Introduzione, esp. p. XXVIII; Chiovenda, Principi, II, p. 70; Betti, Processo civile (dirifto romano), esp. n. $4_{\text {; }}$ Biondi, Istituzioni, esp. § 20; Correia \& Sciascia, Ma- 
12 - Crítica: filosofia do direito. - A questão da unidade ou dualidade do ordenamento jurídico é de relevantes conseqüências, seja no direito substancial, seja na teoria do processo, consequências teóricas e práticas que justificam uma tomada de posição a respeito. Mas ela é em si mesma, acima de tudo, uma questão de filosofia do direito, e por isso deve ser prèviamente discutida no plano das abstrações jurisfilosóficas.

$E$, nesse plano, imediatamente se percebe o sabor normativista da concepção unitária, - o que é muito natural, já que a tese teve a sua formulação básica definitiva justamente na obra do maior de todos os normativistas, Kelsen. Mesmo quando se tenta compreender mais amplamente a experiência jurídica e, num repúdio ao pan-processualismo, atribuir a obra de concretização da norma ao intérprete (expressão muito mais ampla do que juiz), resta-se sempre no campo norma. E será lícito dizer que o direito é a norma, que a experiência jurídica se reduz a esta? Por mais que afirmem a necessidade de uma visão global da experiência jurídica, os unitaristas acabam, paradoxalmente, aproximando-se a uma resposta afirmativa, pois não vêem no ato do devedor que paga, das partes que contratam, que se conciliam, do árbitro que emite um laudo, do juíz que pronuncia uma sentença ou que satisfaz o credor na execução, senão meros elos da cadeia de atividades destinadas à concretização, ou mesmo à criação da norma.

O direito, em verdade, não só na norma vive, mas também no fało ao qual a norma se aplica, e no valor que motiva a enunciação da norma abstrata e que deve presidir a interpretação dos textos em que ela se consúbstancia. $O$ direito se insere na vida do Estado como um instrumento para a realização de certos valôres considerados essenciais à coesão do grupo social e à caminhada em direção dos fins comuns: a emoção atrativa ou repulsiva com que a opinião dominante recebe uma certa massa de fatos (os quais são, dessa forma, considerados lícitos ou ilícitos - ou seja, favorecedores da coesão ou da desagregação social) é um juízo de valor que tende a cristalizar-se em norma jurídica. Ora, nesse quadro é arbitrário concentrar na norma a definição da experiência jurídica, a qual começa com o fato e se dirige ao fato: $i$, é, o sistema normativo é uma resultante da valo-

nual, esp. $\S \S 4.0$ (p. 19 e 9.0 (p. 26); Antokolétz, Tratado de Derecho Romano, cap», I, $\S \S 4 .^{\circ}$ (p. 19 e 14; Arangio-Ruiz, Cours de droit romain, p. 65-67; Carreli, La genesi del procedimento formolare esp. cap. III, § II (p. 51), cap. V, § XXII (p. 225), § XXIIII (p. 227), e $\S X X I V$ (p. 230); Roscoe Pound, Justice, esp. p. p. 60-63, e The spirit, esp. p. p. 13, 21, 182; Farnsworth, An introduction, esp. pp. 61-62; Tunc \& Tunc, Le droit, esp. n.० 31-33; Massitte, Casos, esp. p. 5; Micheli, L'unità, esp. n.० IV; Liebman, Giurïsprudenza; esp. n.० 4, e Diritto e giurisprudizione, esp. p. 86; Calamandrei, II giudice • lo storico, esp. n. ${ }^{10}$; Colesanti, Giurisprudenza, esp. n. $\circ 2$. 
ração de fatos aplaudidos ou redupiados, e se destina à disciplina concreta de fatos futuros que reentrem na mesma categoria dos anteriormente valorados (categoria essa isolada pelo legislador e descrita na hipótese legal).

Essa breve incursão pelo campo da filosofia do direito visa apenas a demonstrar como não se deve inserir no processus de produção da norma concreta a atividade do intérprete (seja êste o juiz, ou os próprios interessados, o árbitro, ou quem quer que seja). Não se nega a sua inserção na experiência jurídica, nem se discute a validade de interpretação do binômio fato-norma segundo os cânones éticos da sociedade atual. O ponto importante a fixar é que o intérprete já encontra uma norma concreta consumada e a sua atividade é meramente recognitiva: as escolhas que a sua tarefa lhe impõe situam-se exclusivamente no plano teorético e nunca no axiológico - de modo que lhe cabe apenas investigar a verdade dos fatos ocorridos, acertando depois se êstes recebem de tal norma a sua disciplina concreta, além de esclarecer qual o sentido atual da norma (ou seja, que valor a opinião atualmente dominante na sociedade pretende tutelar através dela, e de que forma quer tutetá-lo). Não cabe ao intérprete estabelecer um ainda inexistente contato entre o fato e a norma, nem dar a esta o significado que ditarem os seus sentimentos pessoais. Quando êle intervém, já encontra uma realidade consumada (o fato em sua relação lógica com a hipótese da norma geral, o significado axiológico desta e, enfim, a norma concreta que "brotou" do encontro do fato com a norma). E o seu dever é o de ser fiel a essa realidade, referindo-a sem distorsões históricas (quanto ao fato) ou axiológicas (quanto ao valor expresso da norma). Daí resulta que há concretização da norma, i. é, a sua aplicação ao caso concreto, não só independentemente da inserção do intérprete mas também indepentemente da opinião dos próprios sujeitos da relação jurídica e do seu comportamento (controvérsia, satisfação voluntária, etc.).

Na verdade, a inaptidão da norma geral a tornar-se concreta ao simples encontro com o fato previsto hipotèticamente é um ponto-de-fé, um axioma que as teorias monísticas nunca chegaram a demonstrar. O que autoriza a afirmação de que não existe norma, não existe ordenamento jurídico, senão no processo e através do processo? A existência objetiva da lei é um fato, e é também universalmente reconhecido que o fato de sua existência é em si um vínculo à vontade dos homens (vínculo por fôrça do qual a maioria pauta o seu comportamento segundo os cânones queridos pelo legislador). Além disso, se com a sua inobservância cessasse tôda a sua eficácia vinculativa (o que os unitaristas afirmam), que critério outro teria o juíz 
para julgar? Que o juíz julga segundo a lei é um dado de tamanha evidência (confirmado inclusive pelo nosso direito positivo, pois a sentença proferida contra literal disposição de lei é até rescindível: CPC 798), que precisaria mesmo tôda aquela complicada e às vêzes oracular argumentação dos adversários da tese dualista para torcer a realidade, com profundas especulações filosóficas sôbre o homem, o seu valor, a sua ação (especulações que chegam a resultados talvez válidos, mas sem relevância para a questão).

A solução dualista, ao contrário, pauta-se pela simplicidade de sua demonstração, a simplicidade de quem afirma coisas evidentes que não requerem expedientes sutis de argumentação para serem demonstradas, nem especial iniciação do leitor para compreendê-las. Em proposições simples e convincentes, os sustentadores da tese dualista observam os fenômenos em primeiro lugar sôbre um plano objetivo, afirmando que o direito do caso concreto nasce independentemente de qualquer atividade (mesmo teorética) do intérprete, a quem cabe, depois, o acertamento ou a atuação da norma concreta, que é norma e que é concreta antes da inserção do intérprete no mecanismo. Só assim se foge ao absurdo (mal disfarçado pelas sutilezas filosóficas dos defensores das teses monísticas) de que, no caso de satisfação voluntária de interêsse alheio conforme à lei, ou a prestação é feita sem que houvesse direito, ou o direito nasceu justamente com $o$ ato de sua extinção. $\left({ }^{12}\right)$

13 - Críticas: direiło positivo. É chegado o momento de constatar no plano mais humilde do direito positivo se são fundadas as objeções feitas à teoria monista, ou se o nosso ordenamento jurídico é feito para operar unitàriamente, sem aquêle afirmado nítido destaque entre a função legislativa e a jurisdicional. Da análise dogmática de alguns institutos lògicamente dependentes da questão debatida (coisa julgada, efeito retardado da sentença, dívida de jogo), poder-se-á reconstruir a orientação básica do nosso ordenamento.

O mais agudo sintoma de uma tomada de posição da nossa lei frente às duas teses em exame é a vigente disciplina do instituto da coisa julgada. Sabemos que, na história das doutrinas processuais, há duas tendências básicas a respeito dêsse instituto: a teoria material, segundo a qual a coisa julgada tem uma função prevalente de determinar a regra do caso concreto, regra a ser observada daí em diante por todos, mesmo pelos juízes que forem chamados a apreciar a mesma ação, e teoria processual, que sustenta a prevalência, ou mesmo exclusividade, da função negativa da coisa julgada, i. é, função

(12) Reale, Filosofia do Direito, esp. n.0 179 e 196. 
de extinguir a ação, com a consequiência prática de que já não se trata de impor julgamentos futuros conformes ao precedente, mas de impedir tôda e qualquer nova apreciação do mesmo thema decidendum. $O$ ordenamento jurídico brasileiro opta decididamente pela teoria processual, considerando nula e portanto rescindível a sentença proferida com ofensa à coisa julgada (CPC 798, l, b) e reconhecendo essa ofensa sempre que um juíz decidir novamente as questões já decididas, relativas à mesma lide (o CPC 289 afasta-se do conceito de ofensa à coisa julgada contido no art. 395, n. $^{\circ}$ 5, do c.p.c. italiano, segundo o qual só a sentença contrária a uma precedente passada em julgado é revogável). E uma lógica conseqüência disso é que a nossa lei dispõe que o reconhecimento pelo juíz de que há uma sentença precedente com autoridade de coisa julgada levará a um provimento de rito, terminativo do processo (CPC 182, ,II, e 184).

Essa orientação encontra eco na mais antiga e incontrastada tradição luso-brasileira, pois todos os autores, desde o regime das Ordenações e do Regimento 737, até ao dos códigos estaduais e ao do Código de Processo Civil, invariàvelmente afirmam que a existência de coisa julgada impede qualquer nôvo julgamento da mesma matéria (no Brasil, pois, nunca progrediu a tese, alhures afirmada, de que a coisa julgada impõe que no segundo processo eventualmente instaurado seja dada uma sentença de mérito conforme à precedente).

E essa mesma orientação também se projeta para o futuro, pois - Anteprojeto Buzaid (que, a propósito, introduz um louvável aperfeiçoamento, eliminando a injustificável exceção de coisa julgada) estatui que o processo se exingüirá sem julgamento no mérito quando - juíz acolher a respectiva alegação (art. 297, IV), não podendo nenhum juíz decidir novamente as questões já decididas em sentença definitiva, relativas à mesma lide (art. 511).

Ora, essa orientação constante no direito pátrio, a respeito da coisa julgada e das conseqüências processuais do seu reconhecimento, constitui seguríssimo sintoma de que a atividade jurisdicional é considerada pelo ordenamento brasileiro num nível nìtidamente diverso daquêle em que se situa a legislativa, i. é, completamente fora do plano da produção do direito. É que, como é intuitivo, se a coisa julgada tivesse a fôrça de criar direito entre as partes, então o juíz do segundo processo incumbiria julgar no mérito, segundo essa norma criada, pois do contrário não teria sentido falar em criação da norma; como conceber que uma norma concreta seja criada com a finalidade específica de nunca ser aplicada? Aliás; o autor do Anteprojeto anuncia expressamente na sua exposição de motivos a ori- 
entação dualista que depois se revela em artigos da legislação constituenda.

Na regulamentação da eficácia da sentença também reside um elemento de confirmação da tese dualista. Partindo da idéia de que pode trazer prejuízo aos indivíduos a imposição a êles das delongas do processo (em troca do poder de autotutela que um dia lhes foi subtraído), o legislador neutraliza os riscos causados pela espera, outorgando eficácia ex tunc à sentença e por várias formas impedindo que ela acabe por incidir sôbre uma situação diversa daquela existente ao momento da instauração do processo. Entre tantos dispositivos ligados a essa idéia, um básico é o do CPC 166, IV, que dá à citação a eficácia de constituir o devedor em mora, com a consequência que, a partir daí, contam-se juros moratórios em benefício do autor (e essa mesma orientação é mantida no Anteprojeto, cf. art. 246); ora, essa construção também leva a crer que o ordenamento jurídico não vê na sentença o momento do nascimento da norma concreta, porque do contrário seria mais natural que dêsse início aos efeitos daquela a partir do seu trânsito em julgado, antes do qual não haveria, em hipótese, o direito subjetivo (êsse é o tratamento em princípio dado apenas à sentença constitutiva; $v$. infra n. $\left.{ }^{\circ} 14\right)$.

Contra as teses unitárias pan-processualistas (i.é, aquelas que resolvem o ordenamento jurídico no processo, fora do qual não há uma norma concreta, cf. supra, n. $\left.{ }^{\circ} 7\right)$, há ainda o argumento fornecido pela disciplina legal das dívidas de jôgo (CC 1.477-1 479): é um caso em que não há a menor possibilidade jurídica de acertamento judicial, e nem por isso deixa de haver um direito subjetivo, uma obrigação (e tanto isso é verdade, que se houver um pagamento voluntário a importância não é repetível).

Além de tudo isso, não pode ser esquecido que o nosso ordenamento jurídico é todo êle feito para operar em dois planos distintos, havendo normas com diferentes graus de imperatividade, havendo códigos diferenciados (em que, bastante aproximadamente, separa-se a matéria substancial da processual), havendo soluções práticas diversas conforme se trate de questões de mérito ou de forma, havendo, enfim, cada qual com o seu método, seus critérios, suas finalidades, um direito material e um direito processual bem distintos entre si. $\left({ }^{1}{ }_{3}\right)$

(13) Liebman, Efficacia, n.० 8-10, Manuale, n.० 142 e Diritto e giurisdizione; Pereira e Souza, Primeiras Linhas, nota 298; Lobão, Segundas Linhas, notas 281-284; Paula Baptista, Compendio, §§ 115-117; Gusmão, Cousa Julgada, p. 20; Ramalho, Praxe Brasileira, § 232; Ribas, Consolidação, art. 581; João Mendes Jr., Direito Judiciário, p. 144; João Monteiro, 
14 - Figuras particulares. - Defendida a teoria dualista do ordenamento jurídico no plano das abstrações próprias à filosofia do direito e demonstrada a sua aceitação pelo direito positivo brasileiro, resta examinar alguns argumentos comumente lançados contra essa teoria: trata-se das sentenças dispositivas, das injustas e das constitutivas, que são por alguns consideradas como irresistível demonstração da tese oposta ou ao menos como casos de inevitável concessão a esta.

A sentença dispositiva não é uma quarta espécie de sentença, ao lado das três que a doutrina tradicionalmente arrola. A dizer a verdade, o único que a distingue das não-dispositivas é a fonte formal de que emana a norma acertada por ela, ou seja, a circunstância de o juíz julgar segundo critérios menos rígidos que o da lei escrita. Trata-se, nos países de direito escrito, dos casos em que a lei não traça em tôdas as suas linhas o desenho da categoria de fatos sôbre os quais incide a sua previsão, omitindo também, por isso mesmo, a formulação precisa do juízo de valor; assim à vista das particularidades e exigências de cada caso, o juiz formulará êle próprio o juízo de valor que entender apropriado, decidindo conforme essa convicção (no direito brasileiro, exemplifica-se com a fixação de alimentos, a disposição sôbre a guarda de filhos). Mas a liberdade de escolha do juiz não chega ao ponto de confundir a sua atividade com a do legislador: a dêste se pauta por um insondável critério político de conveniência, ao passo que a do juíz consiste sempre em buscar em algum lugar, ainda que no mais recôndito dos sentimentos da sociedade, a norma geral da qual se origina a regra do caso concreto; e tanto é verdade, que o juíz tem o dever de motivar a sentença dispositiva, a qual é ainda sujeita aos recursos normais (nesse sentido é que deve ser apreciada a liberdade aparentemente ilimitada que o CPC 114 dá ao juiz). E não é nada fácil descobrir um caso em que, por ser lacunosa a lei e não ser possível descobrir em nenhuma outra fonte a norma abstrata, possa o juiz criar a regra concreta; daí a discutível utilidade do art. $1 .^{\circ}$ do c.c. suiço, segundo o qual numa situação dessas o juíz decidirá como se fôsse legislador. A sentença dispositiva, tudo somado, em nenhum caso pode deixar de se integrar, conforme o seu objeto, numa das três conhecidas categorias: condenatória, constitutiva, declaratória.

Programa, § 237; Carvalho de Mendonça, Da Ação Rescisória, p. 41; Vidigal, Da Ação Rescisória, n. 0 96; J. F. Marques, Instituições, n.0 1.103; Buzaid, Exposição de Mớivos, n.o 36; Attardi, L'interesse ad agire, esp. cap. III, n.o 8 (p. 210); Aliorio, La pluralità n.० 14; Schwab, Der-Streitgegenstand, § 12; De Stefano, L'oggetto del processo, p. 337; Gabriel Rezende Filho, Curso, n. 0548 e 560; Estellita, Da Cousa Julgada, introdução; Amorim, Da Cousa Julgada no Cível, p. 30; Oliveira Lima, Da Cousa Julgada no Cível, p. 15. 
Nem a sentença injusta constitui um argumento do pêso que muitos the dão. Num plano estritamente jurídico, é impossível determinar a existência da injustiça da sentença, porque ou ela já passou em julgado e a imutabilidade que a reveste impede qualquer apreciação a respeito, ou não passou em julgado e então os seus efeitos estão ainda suspensos, não se podendo falar, nesse caso, de criação de direito. Apenas fora dos limites subjetivos da coisa julgada é que essa injustiça poderá eventualmente ser apreciada, como quando o sucumbente injustiçado propõe ação de perdas-e-danos contra o advogado, alegando negligência dêste (por não ter arguido certos fatos relevantes, por ter deixado de juntar documento decisivo, por ter omitido a interposição de recurso): - mas aí não será julgada novamente a mesma lide, e a injustiça da primeira decisão será conhecida incidenter tanłum, como questão e não como objeto de decisão. Fora do campo jurídico se poderá, sem dúvida, afirmar a injustiça da decisão (e nesses limites se deve reconhecer a fôrça criadora da sentença injusta), mas as instituições humanas carecem de meios para determinar se num dado caso concreto a decisão foi justa ou injusta, e se correspondeu a uma prévia vontade do direito objetivo ou produziu ela própria a norma concreta.

Por fim, a sentença constitutiva. É forçar a realidade das coisas, dizer que através desta o juiz nada mais faz do que declarar um precedente direito ou poder no autor à modificação jurídica, e que é no exercício dêsse direito potestativo que reside o fato concretizador da norma; ou que a norma se concretiza por fôrça de lei, após o acertamento daquele direito. É preciso reconhecer que, ao lado do acertamento do direito à modificação jurídica, a sentença constitutiva contém um segundo momento lógico, em que o juíz, inserindo-se com isso no processus de produção da norma concreta, causa a alteração jurídica desejada pelo autor, i. é, modificada a vontade do direito objetivo válida para as relações apreciadas na sentença. Assiste-se, então, a uma inversão da disciplina dogmática da coisa julgada e da eficácia da sentença -- dados que constituem seguro ponto de apôio para dirimir a disputa entre a teoria dualista e a unitária: a sentença constitutiva tem (salvo exceções, cf. CC 158) eficácia ex nunc (claramente reveladora da idéia de que se trała de situação jurídica nova), e a sua parte dispositiva passa a ser regra concreta que as partes observarão doravante para todos os efeitos, i.é, válida para tôdas as relações em que a sua presença possa ser relevante (devendo, inclusive, ser conhecida em eventual sentença que aprecie tais relações dependentes). Mas, sob o aspecto da polêmica entre as duas teorias, a sentença constitutiva é uma simples exceção e não autoriza que se façam afirmações muito genéricas, ao ponto de afirmar que 
em todos os casos a norma concreta não nasce senão mediante a sentença (seja esta de que classe for) ou em geral, mediante a obra do intérprete. A demonstrar a sua excepcionalidade como argumento em favor da tese unitária, está a circunstância de que muitos dos processos constitutivos não pertencem à função jurisdicional do juíz, mas à jurisdição voluntária, mediante a qual êste simplesmente assiste o interessado na administração de certos interêsses privados (e tanto assim é, que as sentenças proferidas em processos de jurisdição graciosa não recebem a autoridade da coisa julgada, devendo ser rescindidas pelas vias ordinárias; i. é, a sua eficácia é comparável à de um ato privado). (14)

15 - Aplicações. - O quesito da unidade ou dualismo do ordenamento jurídico, que aqui vimos em seus aspectos principais e coIhendo em sua essência as formulações doutrinárias básicas, é uma questão metodológica que se situa à cabeceira da teoria do processo, de tal modo que desprezá-la significaria caminhar às escuras entre um emaranhado de institutos cuja disciplina harmoniosa depende de uma tomada de posição a respeito de um denominador comum, de um elemento coordenador. A sua solução deve estar conscientemente presente na solução dos diversos problemas particulares da ciência do processo, que essa é a única forma de evitar graves contrastes lógicos que certamente comprometeriam qualquer doutrina científica como tal.

A sua mais eloqüente manifestação talvez seja sôbre a questão do escopo da jurisdição (ou escopo do processo, como preferem outros), a qual é tão ìntimamente ligada ao das relações entre direito substancial e processo, que quase se pode dizer que ambos não são senão uma só questão, vista de ângulos diferentes. A respeito, veja-se que das três teorias fundamentais que hoje se dividem as preferências dos juristas, apenas uma (a de Chiovenda) é a expressão de uma solução dualística, enquanto que as outras duas (Carnelutti e Redenti) são nìtidamente ligadas à unidade do ordenamento jurídico. Quando dizia Chiovenda que a função jurisdicional visa à atuação da (preexistente) vontade concreta da lei, já com isso afirmava que a norma é concreta independentemente da participação dos órgãos da jurisdição. Mas essa participação é pressuposta na teoria dos comandos complementares de Carnelutti, e tanto que para êle a jurisdição tem o escopo de compor (i. é, de disciplinar) a lide, - coisa que para os

(14) Chiovenda, Principi, § 18, 11; Liebman, Efficacia, n. 6, Manuale, n. 26, e La cosa giudicała; Calamandrei, Istituzioni, $\S 9.0$, e La relatività, n.० 8; J. F. Marques, Instituições, n. 0 282, 853, 1.073, e Jurisdição Voluntária, cap. IX, B (p. 213 e segs.); Raselli, Le sentenze determinative, n. 0 30; Montesano, Condanna civile e tutela esecutiva, $\S 29$; Mortaria, Principii, n. 018. 
seguidores da teoria dualista só pode ser tarefa do direito substancial. Na opinião de Redenti, por fim, a jurisdição se destina a aplicar as sanções e garantias previstas e impostas pelo direito; as normas jurídicas, difusas pelo ordenamento, enunciam a necessidade de certa conduta e ligam à inobservância desta uma ameaça, ou remédio, que consiste justamente na sanção, a qual mais tarde, se houver provocação do interessado, será aplicada pelos órgãos da jurisdição; ora, é viva a presença de Bülow e Kelsen nessas afirmações, as quais só são lògicamente aceitáveis (prescindindo-se de outras críticas) dentro do sistema unitário do ordenamento jurídico.

Esse sistema favorece também a tese de que o direito subjetivo tem por objeto uma prestação alheia, i. é, que êle é um direito a um comportamento e não a um bem. Talvez no direito romano a tese fôsse aceitável, quando não havia execução pairimonial e o que se fazia, com a manus injectio, era pressionar o obrigado (mediante encarceramento, venda no mercado e até mesmo morte) e criar em sua vontade a determinação de cumprir o mandamento da lei. Mas desde o momento em que a execução passou a ser feita sôbre o patrimônio do devedor, do qual é tirado o bem devido ou o seu equivalente econômico independentemente da vontade dêste, a doutrina se tornou insustentável - e, para salvá-la, foi preciso dizer que num dado momento o direito sofre uma metamorfose, passando a ter por objeto já o bem devido e não o comportamento da parte contrária; ou que com a condenação a obrigação se transforma em sujeição à autoridade dos órgãos executórios, no sentido de que o titular ativo já não tem direito à prestação, mas à sanção a ser atuada sôbre o devedor (essa é a teoria de Calamandrei sôbre a condenação civil). Mas, quem assumir a teoria oposta (dualista) terá propensão a dizer que objeto do direito subjetivo é originàriamente um bem, com referência ao qual a lei dá a uma pessoa uma posição de vantagem sôbre outra; e a execução forçada perseguirá esse mesmíssimo objeto (ou o seu equivalente econômico), sem que sejam necessários expedientes de argumentação (como ○ da metamorfose do direito) para justificar o fenômeno. A obrigação e o processo (notadamente o de execução) podem, então, ser considerados dois instrumentos preordenados à atuação da vontade da lei, - instrumentos dos quais o segundo só é disponível se o primeiro tiver sido ineficaz a afastar a controvérsia.

Não havendo qualquer alteração na situação jurídica substancial através da sentença condenatória, i. é, sendo meramente declarado um direito subjetivo preexistente, a prescrição que reinicia a fluir $\exists$ 
partir dessa sentença se conta pelo mesmo prazo da que antes corria (segundo a natureza do direito), e que ficou interrompida pela citação e impedida pela pendência do processo. Dessa forma, a adoção da teoria dualista é decisiva para afastar a opinião de que a prescrição de que trata o CPC 1.010, II, é a ordinária por se tratar de um direito novo, para o qual não há especial previsão.

A ação, na teoria dualista, é considerada distinta do direito subjetivo substancial, seja como direito à sentença favorável (teoria concreta), seja como poder de exigir uma sentença de mérito (teoria abstrata); é através dela que uma das pessoas empenhadas na controvérsia usa de um dos instrumentos que a lei the põe à disposição (ou seja, o processo). Na teoria unitária, ao contrário, ela se identifica com o direito subjetivo incerto ou insatisfeito (Satta), ou mesmo é o único direito que realmente existe (Pekelis).

E uma consequência disso é que o título executivo (em geral) seria mero documento de legitimação formal da execução, pois não teria sentido, na teoria unitária, ligá-lo à criação da ação executiva.

Outra coisa que não teria sentido seria a discussão sôbre a pertinência dos institutos da hipoteca, da prova, da coisa julgada, ao direito processual ou ao direito substancial, pois êstes dois estariam como que fundidos em um só; mas se nota que a tendência dos unitaristas é levar êsses institutos para a teoria do direito substancial, sendo oposta a tendência dos dualistas.

Êsses não são meros exemplos dos incontáveis institutos processuais em que está presente a influência da questão das relações entre o direito substancial e o processo; a menção a essas conseqüências da polêmica não pode ter outro sentido senão o de salientar a relevância desta e mostrar como ela não se resolve numa estéril disputa acadêmica. E mesmo as presentes notas, escritas sob a convicção da vantagem da tese dualista sôbre a concepção adversária, têm muito menos a finalidade de defender aquêle ponto-de-vista do que a de chamar a atenção para o problema metodológico fundamental. O importante não é a utópica concordância de todos sôbre os problemas científicos do direito, mas a coerência com que cada um sustenta os próprios pontos-de-vista; e essa coerência não se atinge se não houver uma diretriz constante na apreciação dos diversos institutos em particular. ${ }^{15}$ )

(15) Redenti, Intorno al concetro di giurisdizione, esp. n. 0 II; Barbero, II diritto soggettivo; Calamandrei, La condanna, n. $\circ$ 4-5; Vidigal, Escopo do Processo Civil. 


\section{B I B L I O G R A F I A}

Allorio, La pluralità degli ordinamenti giuridici e l'accertamento giudiziale, in Rivista di diritto civile, 1955, p. 247.

Amorim, da Coisa Julgada no Cível, Typographia do Forum, Belo Horizonte, 1899.

Antokoletz, Tratado de Derecho Romano, ed. El Ateneo, Buenos Aires, 1930.

Arangio-Ruiz, Cours de droit romain, ed. Jovene, Nápoles, 1935.

Ascarelli, Giurisprudenza costituzionale e teoria dell'interpretazione, in Rivista di diritto processuale, 1957.

- In tema di interpretazione ed applicazione della legge, in Rivista di diritio processuale, 1958.

Attardi, L'interesse ad agire, Cedam, Pádua, 1958.

Barbero, II diritto soggettivo, ed. Foro it., Roma, 1939.

Betti, Processo civile (diritto romano), in Novissimo Digesto Italiano.

Biondi, Istituzioni di diritto romano, Giuffrè, Milão, 1944.

Buzaid, Exposição de Motivos ao Anteprojeto de Código de Processo Civil, Imprensa Nacional, Rio, 1964.

Calamandrei, La condana, in Studi sul processo civile, Cedam, Pádua, 1934.

- II giudice e lo storico, in Rivista di diritto processuale, civile, 1939.

- Istituzioni di diritto processuale civile, Cedam, Pádua, 1943.

Caprograssi, Giudizio processo scienza verità, in Rivista di diritto processuale civile, 1950, p. 7.

- Intorno al processo, in Rivista internazionale di filosofia del diritto, 1938, p. 254.

Carnelutti, Diritto e processo, ed. Morano, Nápoles, 1958.

- Istituzioni del processo civile italiano, ed Foro it., 1956.

- La sentenza condizionale, ed. Società Editrice Libraria, Milão, 1920.

Carrelli, La genesi del procedimento formolare, Giuffrè, Milão, 1946.

Carvalho de Mendonça, Da Ação Rescisória das Sentenças e Julgados, Livraria Francisco Alve,s Rio, 1916.

Chiovenda, Principi di diritto processuale civile, ed. Jovene, Nápoles, 1928.

Colesanti, Giurisprudenza, in Novissimo Digesto Italiano.

Correia \& Sciascia, Manual de Direito Romano, Saraiva, São Paulo, 1953.

De Fina, Ordinamento e giurisdizione - una polemica tra processualisti, in Rivista di diritto processuale, 1969.

De Stefano, L'oggetto del processo in un libro recente di Walter H. Habscheid, in Rivista trimestral di diritto e procedura civile, 1957, p. 337.

Estellita, Da Cousa Julgada, Rio, 1936 (sem editôra).

Fazzalari, L'esperienza del processo nella cultura contemporanea, in Studi in onore di Antonio Segni.

- Note in tema di diritto e processo, Giuffré, Milão, 1957.

Farnsworth, An Introduction to the Legal system of the United States, ed. Columbia University, 1963.

Gusmão, Cousa Julgada, Duprat, São Paulo,1914.

Kelsen, Reine Rechtslehre, ed. Deuticke, Leipzig-Viena, 1934 (tradução italiana de Treves: La dottrina pura del diritto, ed. Einaudi, Turim, 1963). 
Liebman, Diritto e giurisdizione (note polemiche), in Rivista di diritto processuale, 1969.

- Efficacia ed autorità della sentenza, Giuffrè, Milão, 1962.

- Giurisprudenza, in Nuovo Digesto Italiano

- Manuale di diritto processuale civile, Giuffrè, Milão, 1957.

Lobão, Segundas Linhas sôbre ○ Processo Civil, Forense, Lisboa, 1869.

Marques, J. F., Instituições de Direito Processual Civil, Forense, Rio, 1960.

- Ensaio sôbre a Jurisdição Voluntária, Revista dos Tribunais, S. Paulo, 1952.

Mendes Jr., Direito Judiciário Brasileiro, Freitas Bastos, Rio - São Paulo, 1940.

Micheli, L'unità dell'ordinamento e il processo civile, in Rivista di diritto processuale, 1968.

Monteiro, Programma da Curso de Processo Civil, Duprat, São Paulo, 1912.

Montesano, Condanna civile e tutela esecutiva, Jovene, Nápoles, 1955.

Mortara, Commentario del codice e delle leggi di procedura civile, ed. Vallardi, Milão, 1923.

- Principii di procedura civile, ed. Barbera, Florença, 1904.

Muther, Zur Lehre von der römischen Actio, dem heutigen Klagerecht, der Litiscontestion und der Singularsucession in Obligationen, ed. Buddeus, Düsseldorf, 1856 (tradição italiana de Pugliese \& Heinitz: Sulla dotrrina dell'"' actio" romana, dell' odierno diritto di azione, della "litiscontestatio" e della sucessione singolare nelle obbligazioni) - v. Pugliese.

Oliveira Lima, Da Cousa Julgada no Cível, Typographia Industrial, Recife, 1855.

Paula Baptista, Compendio de Theoria e Pratica do Processo-Civil Comparado com o Commercial, Garnier, Rio-Paris, 1907.

Pekelis, Azione (teoria moderna), in Novissimo Digesto Italiano.

Pereira e Sousa, Primeiras Linhas sôbre o Processo Civil, Imprensa Litteraria, Coimbra, 1872.

Pugliese, Azione (diritto romano), in Novissimo Digesto ltaliano.

- Introduzione a Polemica intorno all"actio", ed. Sansoni, Florença, 1954 (trata-se de uma coletânea que reúne os dois trabalhos de Windscheid e o de Muther, mencionados nesta relação).

Ramalho, Praxe Brasileira, Typographia do Ypiranga, São Paulo, 1869.

Raselli, Le sentenze determinative e la classificazione generale delle sentenze, in Scritti giuridici in onore di Francesco Carnelutti, Cedam, Pádua, 1950.

Reale, Filosofia do Direito, Saraiva, S. Paulo,1969.

Redenti, Intorno al concetto di giurisdizione, Jovene, Nápoles, 1916.

Rezende Filho, Curs̀o de Direito Processual Civil, Saraiva, São Paulo, 1950.

Ribas, Consolidação das Disposições Legislativas e Regulamentares Concernentes ao Processo Civil, Typographia Nacional, Rio, 1878.

Rocco, Alfredo, La sentenza civile, Giufrè, Milão, 1962.

Roscoe Pound, Justice According to Law, Yale University Press, 1951 (tradução brasileira de Monteiro: Justiça Conforme a Lei, ed. Ibrasa, S. Paulo, 1965).

- The Spirit of the Common Law, Marshall Jones Comp., Boston, 1921.

Schwab, Der Streitgegenstand im Zivilprozess, ed. Becksche, Munique-Berlin, 1954 (tra. dução argentina de Banzhaf: El Objeto Litigioso en el Processo Civil, Ejea, Buenos Aires, 1968).

Tunc \& Tunc, Le droit des Etats-Unis, Dalloz, Paris, 1955. 
Vidigal, Da Ação Rescisória dos Julgados, Saraiva, São Paulo, 1948.

Von Bülow, Die Lehre von den Processeinreden und die Processvoraussetzungen, ed. Roth, Giesen, 1868 (tradução argentina de Lichtschein: La Teoria de las Excepciones Processales y los Presupuestos Procesales, Ejea, Buenos Aires, 1964).

Windscheid, Die Actio des römischen Civilrechts vom Stand punkte des heutigen Rechts, ed. Buddeus, Düsseldorf, 1856 (tradução italiana de Pugliese \& Heinitz: L' "actio" del diritto odierno) civile romano dal punto di vista del diritto odierno) v. Pugliese.

- Die Actio, Abwehr gegen Dr. Muther, ed. Buddeus, Düsseldorf, 1857 (tradução italiana de Pugliese \& Heinitz: L"'actio". Réplica a Th. Muther) - v. Pugliese. 